\title{
A NEW TELIPOGON FROM MEXICO CLOSE TO TELIPOGON STANDLEYI (ORCHIDACEAE: ONCIDIINAE)
}

\author{
DiEgo BOGaRín \\ Jardín Botánico Lankester, Universidad de Costa Rica. P.O. Box 302-7050 Cartago, Costa Rica, A.C. \\ Herbario UCH, Universidad Autónoma de Chiriquí, P.O. Box 0427, Chiriquí, Panamá. \\ diego.bogarin@ucr.ac.cr
}

\begin{abstract}
A new Telipogon from Mexico, previously confused with T. standleyi from Costa Rica, is described and illustrated. Telipogon amoanus is recognized by the pink-purplish flowers, the obliquely ovate, subfalcate sepals, the elliptic, entire petals, the triangular sagittate lip, densely pilose column with short basal hairs, and the pollinarium with the stipe obtrullate. Telipogon standleyi is illustrated based on Costa Rican material to facilitate species comparison. Additional comments on both species are provided.

Resumen. Se describe e ilustra un nuevo Telipogon de México, previamente confundido con T. standleyi de Costa Rica. Telipogon amoanus se reconoce por las flores de color rosa-púrpura, los sépalos oblicuamente ovados, subfalcados, los pétalos elípticos, enteros, el labelo triangular sagitado, densamente piloso, la columna densamente pilosa, con pelos cortos en la base y el estípite del polinario obtrulado. Para facilitar la comparación entre especies se ilustra Telipogon standleyi basado en material de Costa Rica. Se proporcionan comentarios adicionales sobre ambas especies.
\end{abstract}

Key words: Stellilabium, Telipogon amoanus, new species, taxonomy

Williams et al. (2005) evaluated the phylogenetic relationships of Telipogon Kunth and related genera by using molecular datasets. Their results showed that Stellilabium Schltr. was embedded within Telipogon, which consists of one Central American and two South American clades. Traditionally, Stellilabium was recognized as having small flowers with a simple column and a tendency to leaflessness, often lacking leaves when the plants are in flower. According to Williams et al. (2005) that condition has arisen at least twice, once in South America and once in Central America. Stellilabium was treated taxonomically by Braas and Lückel (1982), Garay and Romero-González (1998) and Dressler (1999).

Telipogon ranges from Mexico, through Central America and the Caribbean to Bolivia, but the highest species diversity is found in the Andes. In Central America the majority of species are concentrated in Costa Rica and Panama, with few members from Mexico to Nicaragua. Only two species were recorded in Mexico, both classified under the former Stellilabium. Salazar \& Hágsater (1991) published the first record as Telipogon (=Stellilabium) standleyi Ames from Guerrero. The second record is Telipogon helleri (L.O. Williams) N.H.Williams \& Dressler, recently documented by Solano et al. (2011) from Chiapas.

Oakes Ames described T. standleyi from a plant collected by Paul Standley in 1924 in Costa Rica between Tarbaca and Aserrí, southeast of San José (Ames 1925). In 2008, during a field trip near the type locality of $T$. standleyi, a plant in flower was collected for documentation and cultivated at Lankester Botanical Garden.

In revising the specimen reported by Salazar and Hágsater (1991), I realized that it markedly differs from the Costa Rican specimens. The Mexican species is treated here as a new to science and it is described hereafter:

Telipogon amoanus Bogarín, sp. nov.

TYPE: MÉxico. Guerrero: Camino ChilapaHueycatenango $\mathrm{km}$ 22. Preparado de material cultivado, 15 de noviembre de 1975, E. Hágsater 4641 (holotype, AMO). FIG. 1.

Telipogon standleyi aemulans, differt floribus roseis, sepalis oblique ovatis subfalcatis, petalis 

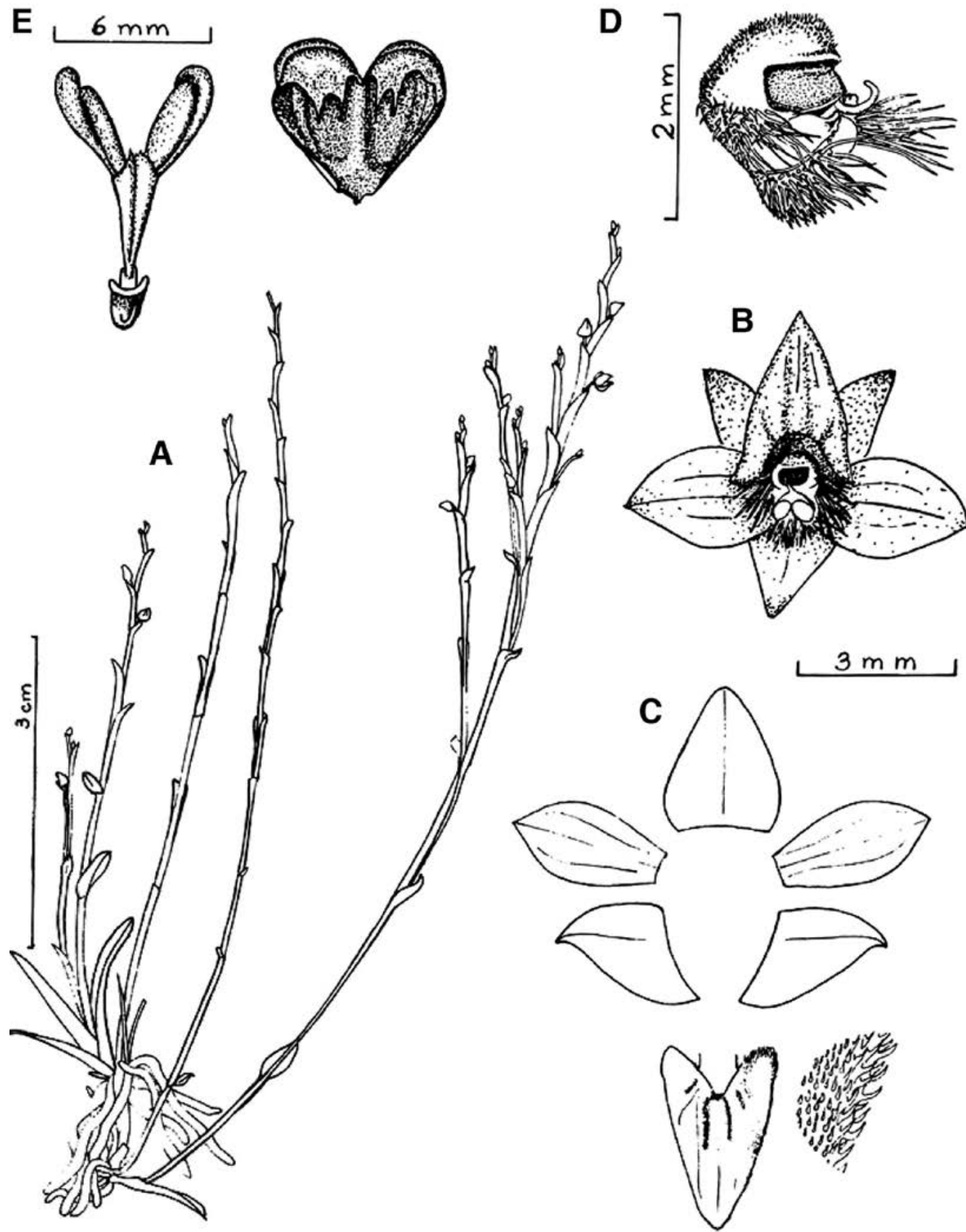

Figure 1. Telipogon amoanus Bogarín. A - Habit. B - Flower. C - Perianth flatten. D - Column. E - Pollinarium and anther cap. Drawn by E. Hágsater from the holotype. 
ellipticis integris, labello triangulato sagittato dense piloso, columna confertim pilosa basaliter pilis brevis vestita, stipite pollinarii obtrullato.

Epiphytic, acaulescent herb, ca. $9 \mathrm{~cm}$ tall including the inflorescences. Roots thick, fleshy, slightly flattened, white with green tips, $c a .1 .5 \mathrm{~mm}$ in diameter. Leaves deciduous when flowering, erect, distichous, linear-lanceolate, acute, somewhat fleshy (very thin and translucent when dry), 7.5-22.0 $\times$ 1.5-2.0 mm. Inflorescences several (5 in our material), simultaneous, developed from leaf axils, simple or branched, up to $90 \mathrm{~mm}$ long, scape compressed, green, $0.5-1.0 \mathrm{~mm}$ thick, with 2-3 spaced and small, triangular-ovate, acute-attenuate, green, translucent bracts, with a thickened vein $2.4-4.5 \times 0.8-1.5 \mathrm{~mm}$. Floral bracts very small, broadly ovate-deltate, acute to shortly acuminate, green, translucent, with a thickened vein, $1.2-1.5 \times 1.0-1.6 \mathrm{~mm}$. Ovary slightly curved, terete, $2.0-2.5 \mathrm{~mm}$ long and $0.5-0.7 \mathrm{~mm}$ thick. Flowers small, inconspicuous, 5-7 $\mathrm{mm}$ in diameter, sepals and petals rose slightly yellow towards the apex, the lip pink with some yellow apical spine and purple anthers, a few scatter idioblasts containing crystalline material are evident in the floral parts. Dorsal sepal ovate, obtuse-rounded, concave, 1-nerved, glabrous, $2.5-3.0 \times 1.6-2.0 \mathrm{~mm}$. Lateral sepals obliquely ovate, acute, concave, 1-nerved, glabrous, 2.5-3.0 $\times 1.8-2.1 \mathrm{~mm}$. Petals elliptic, obtuse to subacute, slightly concave or flat, 3-nerved, $2.8-3.5 \times 1.5-2.1$ $\mathrm{mm}$, dense and shortly pilose internally in the basal third, the margins glabrous to conspicuously ciliate on the basal two-thirds, the cilia retrorse. Lip sessile, with a shallow basal groove clearly separated from the column, entire, very fleshy-thickened in basal half, triangular-sagitate, acute, the inner surface densely and shortly pilose, the margins ciliate (cilia and hairs retrorse), outer surface glabrous, $3.0-3.5 \mathrm{~mm}$ in total length, including the basal auricles, $2.0-2.5 \mathrm{~mm}$ wide between the basal auricles; basal auricles retrorse, free, triangular, subacute, 0.5-0.8 mm long. Column sessile, very short, lobed, $1.5-1.8 \mathrm{~mm}$ in diameter, densely and shortly pilose, with slightly longer hairs on the ventral surface and a bundle of very long, rigid, septate hairs at the apex of each lobe (i.e. one apical and one on each side). Anther cordate, apparently bilocular without obvious septa, ca. $0.8 \times 1.2 \mathrm{~mm}$. Pollinia 4 , subclavate, slightly compressed and overlapping more or less dorsiventrally, in two pairs, yellow, united to a short, obtrullate, translucent stipe terminating into a large, hooked viscidium, rostellum laminar, projected on a narrowly triangular extension. Stigma suborbicular, slightly concave. Capsule not seen.

HавітAт: Acccording to Salazar and Hágsater (1991), plants grow epiphytic on branches with lichens, in mixed forest of pine and oak approximately between 1500 and $2000 \mathrm{~m}$ elevation. Other orchids growing in the area include: Hintonella mexicana Ames, Oncidium ghiesbreghtianum A.Rich. \& Galeotti, Epidendrum marmoratum A. Rich. \& Galeotti and Encyclia atrorubens (Rolfe) Schltr.

Distribution: Known only from Guerrero, Mexico.

Eтymology: it is a pleasure to name this species after the staff and researchers of AMO Herbarium, in recognition of their outstanding contributions to the knowledge of the orchids of Mexico and the Neotropics.

Phenology: plants flower in cultivation in November and February.

Comparison of the material collected in Mexico with living plants of $T$. standleyi from the type locality in Costa Rica lead to reconsider the application of the name T. standleyi for the Mexican populations (Salazar \& Hágsater 1991, see picture in Hágsater et al. 2005, p. 246). Ames (1925) recognized T. standleyi as having the glandular hairs of the column much abbreviated and in being a dwarf plant with foliage present at flowering time. The flowers are yellow with a purple-brown tinged center, the base of the petals and labellum are more deeply colored than the upper half, with a deep purple column. All these characters are consistent with the material studied from the type locality and the type specimen kept at AMES (Fig. 2).

Telipogon amoanus can be recognized from $T$. standleyi by the pink-purplish flowers (rather than yellow with a dark purple or crimson center), the sepals obliquely ovate, subfalcate (rather than triangular, acute), the elliptic, entire petals (rather than ovate, ciliate), the lip triangular sagittate, densely pilose (rather than oblong, basally glandular and glabrous towards the apex), the column densely pilose with short hairs basally (rather than with few abbreviated hairs, basally glabrous) and the pollinarium with the stipe obtrullate (rather than filiform). 

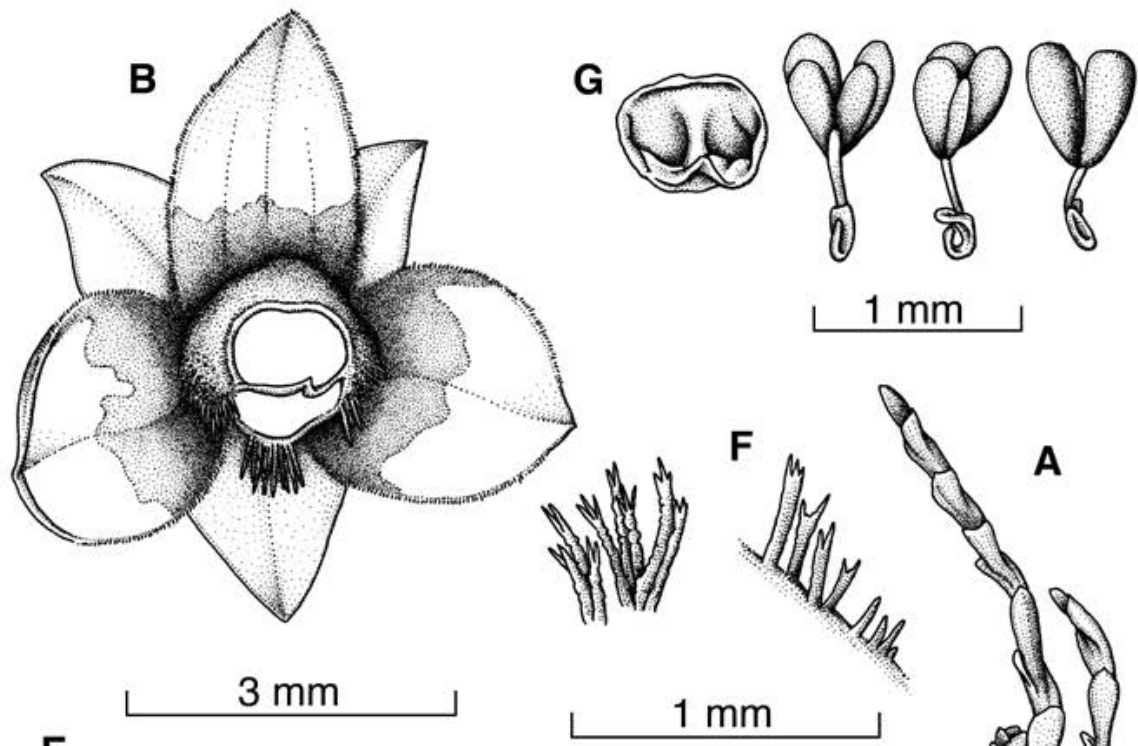

E
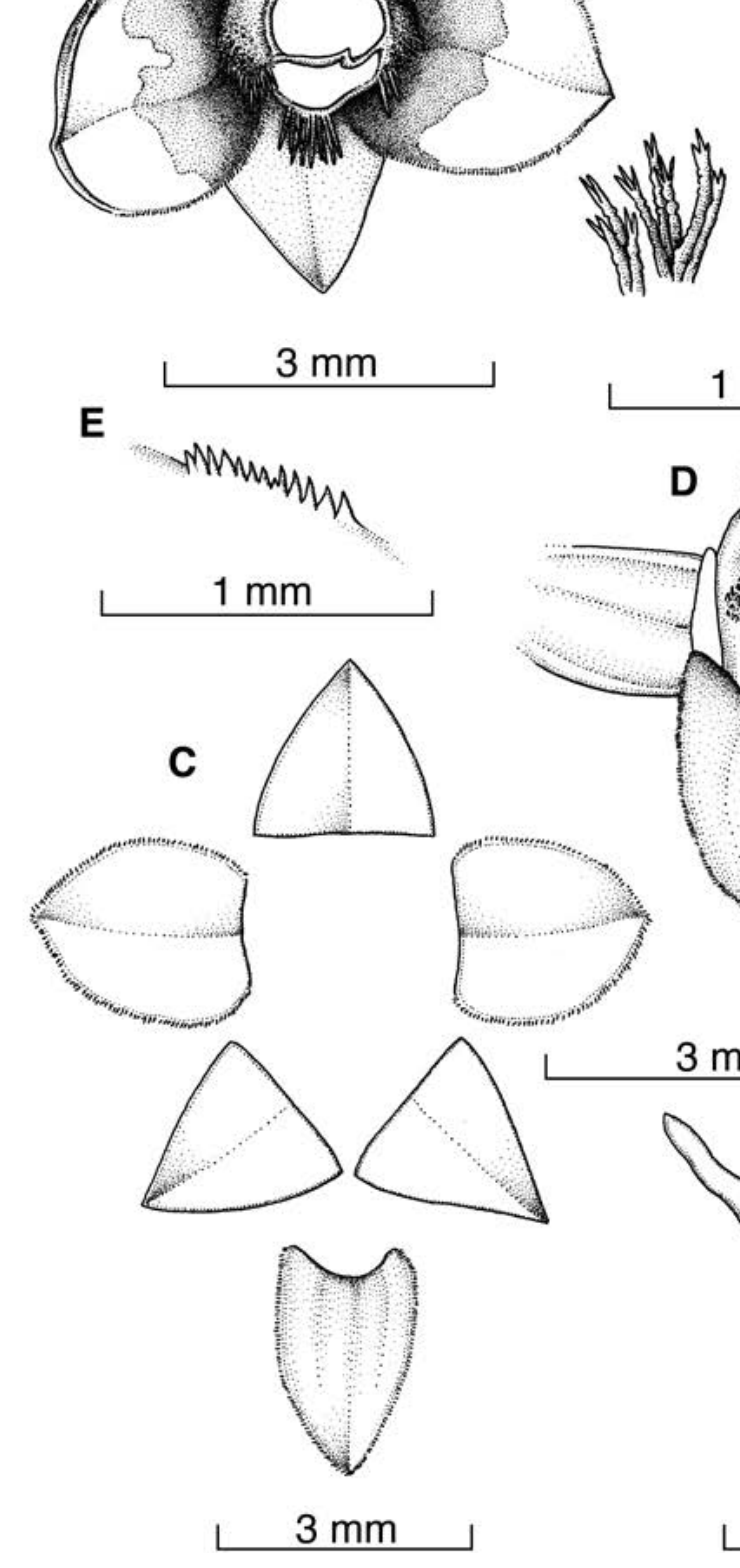

$1 \mathrm{~mm}$
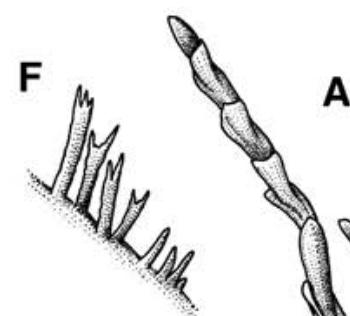

A

D
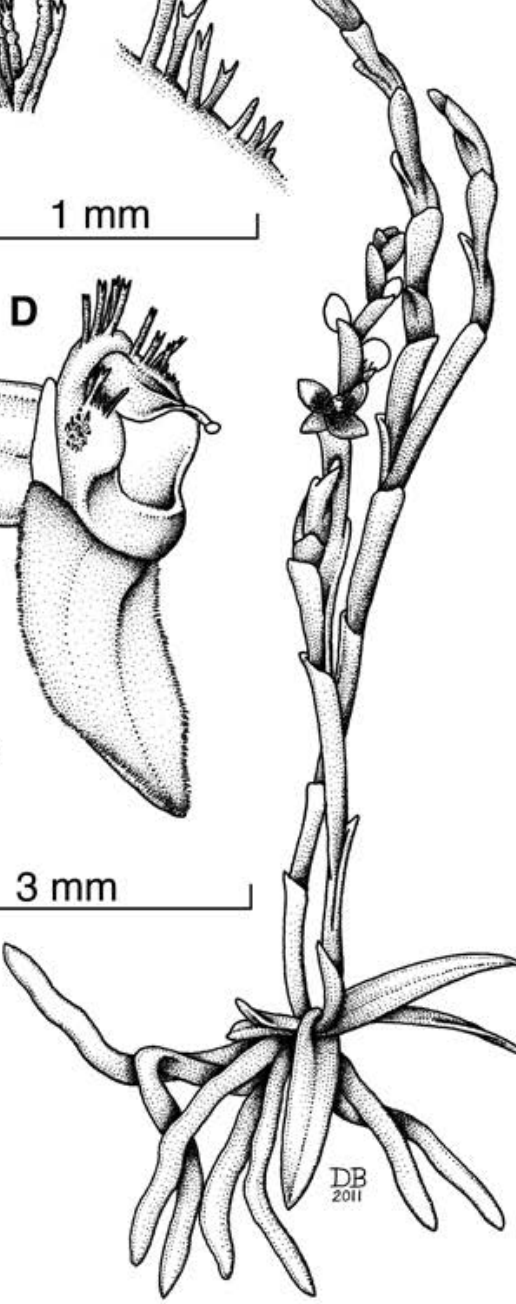

$3 \mathrm{~cm}$

Figure 2. Telipogon standleyi Ames. A - Habit. B - Flower. C - Perianth flatten. D — Column and lip, lateral view. E Margin of lip. F - Bristles of the column. G - Anther cap and pollinarium. Drawn by D. Bogarín based on Bogarín 5138 (JBL-spirit). 

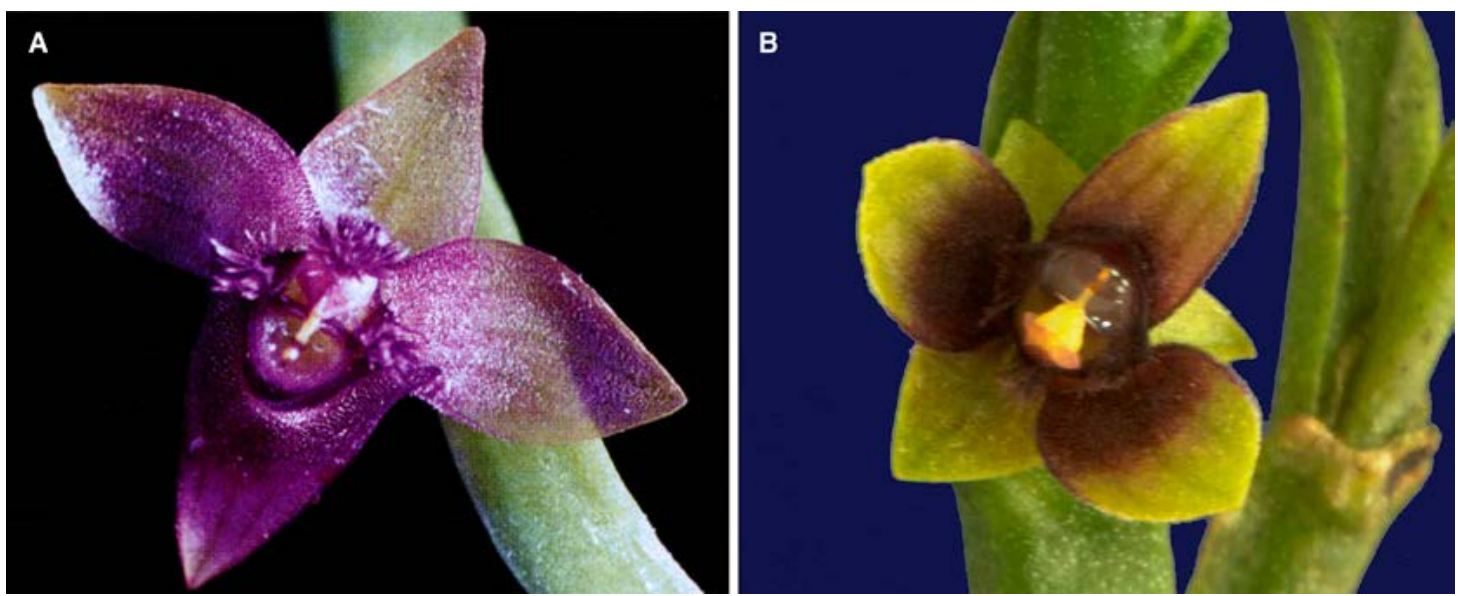

Figure 3. Photo of: A - Telipogon amoanus (from Hágsater 4641). B — T. standleyi (from Bogarín 5138). Photographs by

E. Hágsater (A) and D. Bogarín (B).

Telipogon amoanus is also similar to Telipogon helleri, which is distinguished by having a fringe of hairs in front of the column and lacking the hairs at the apex of the column (present in T. amoanus and $T$. standleyi) (Hamer 1985; Solano et al. 2011).

Acknowledgements. To the Ministerio del Ambiente, Energía y Telecomunicaciones de Costa Rica (MINAET) and Sistema Nacional de Áreas de Conservación (SINAC) of
Costa Rica for issuing the Scientific Passport N. 1862 under which wild specimens treated in this study were collected. I am grateful to Franco Pupulin and Adam Karremans for their useful comments on the manuscript. This paper is part of the Project 814-A7-015, "Inventario y taxonomía de la flora epífita de la región mesoamericana (Orchidaceae)", sponsored by the Vice-Presidency of Research, University of Costa Rica. To Eric Hágsater for granting permission to publish his drawing and photograph.

\section{LITERATURE CITED}

Ames, O. 1925. New or noteworthy species of orchids from the American Tropics. Schedul. Orch. 9: 1-62.

Braas, L.A. \& E. Lückel. 1982. Die Gattungen mit Bestimmungsschlüssel der Telipogon-Verwandtshaft (Subtribus

Telipogoninae Schltr.: Telipogon Kunth., Trichoceros Kunth, Stellilabium Schltr., Dipterostele Schltr., Darwiniella Braas \& Lückel. Orchidee (Hamburg) 33: 170-176.

Dressler, R.L. 1999. A reconsideration of Stellilabium and Dipterostele. Harvard Pap. Bot. 4: 469-473.

Garay, L.A. \& G.A. Romero-González. 1998. Schedulae Orchidum. Harvard Pap. Bot. 3: 53-62.

Hágsater, E., M. A. Soto Arenas, G. A. Salazar Chávez, R. Jiménez Machorro, M. A. López Rosas \& R. L. Dressler. 2005.

Las orquídeas de México. Instituto Chinoín México, D.F. 304 pp.

Hamer, F. 1985. Stellilabium helleri L. O. Wms. Icones Plantarum Tropicarum 13: PI. 1293.

Salazar, G.A. \& E. Hágsater. 1992. Stellilabium standleyi, único representante mexicano de la subtribu Telipogoninae (Orchidaceae). Orquídea (Mexico City) 12(2): 231-236.

Solano Gómez, R., R. Jiménez Machorro \& A. A. Damon. 2011. Two new records and one rediscovery for Orchidaceae of Mexico. Act. Bot. Mex. 96: 59-72

Williams, N.H., W.M. Whitten \& R. L. Dressler. 2005. Molecular systematics of Telipogon (Orchidaceae: Oncidiinae) and its allies: nuclear and plastid DNA sequence data. Lankesteriana 5: 163-184. 